\title{
A low diversity Sinuites gastropod community from the Floian, Early Ordovician, of South Wales
}

\author{
Jan Ove R. Ebbestad and John C.W. Cope \\ Acta Palaeontologica Polonica 66 (2), 2021: 319-335 doi:https://doi.org/10.4202/app.00854.2020
}

A low diversity Sinuites-dominated gastropod community is described from the Floian, Arenig Series, of the Llangynog Inlier, southwest of Carmarthen, South Wales. The abundant material comes from shallow-water siltstone and mudstone beds of the Bolahaul Member of the Ogof Hên Formation. The locality has an exceptionally diverse mollusc-dominated fauna (63.5\% of the fauna), with gastropods constituting $6 \%$ and tergomyans $1 \%$ and echinoderms, arthropods and other fauna making up the rest. Except for one rare tergomyan mollusc, identified as Carcassonnella $\mathrm{cf}$. vizcainoi, other tergomyans are described elsewhere. Nearly half of all gastropod specimens are represented by Sinuites ramseyensis . Three of the five taxa described are new: Mimospira llangynogensis sp. nov., Catalanispira prima sp. nov., and Ceratopea? moridunensis sp. nov. The assemblage compares best with those of contemporaneous high-latitude peri-Gondwana areas. Early Ordovician species of Carcassonnella are typically found in France, Iberia, Czech Republic, and Morocco, while species of Mimospira are found in Germany and Czech Republic, but also in Baltica where the main radiation took place later. Two of the oldest occurrences of Mimospira are from Avalonian Wales (Carmarthenshire and Anglesey). Catalanispira occurs later in Baltica and Laurentia in the late Middle and early Late Ordovician, when taxa from these areas start to appear in Wales and vice versa. The presence of Ceratopea?, a genus typical of Laurentia, is at odds with the biogeographic distribution of faunas at this time. Part of the observed distribution pattern may be explained by different latitudinal position and facies depths of Avalonia compared to Armorica, Bohemia, and Morocco. The species described herein are amongst the first Floian taxa of these groups formally described from this area and add significantly to the global Floian record.

Key words: Gastropoda, Onychochilidae, Tergomya , biogeography, Floian, Arenig, Ordovician, Avalonia, UK.

Jan Ove R. Ebbestad [jan-ove.ebbestad@em.uu.se], Museum of Evolution, Uppsala University, Norbyvägen 16, SE 75236 Uppsala, Sweden. John C.W. Cope [john.Cope@museumwales.ac.uk], Department of Natural Sciences, National Museum of Wales, Cathays Park, Cardiff CF10 3NP, UK. 
This is an open-access article distributed under the terms of the Creative Commons

Attribution License (for details please see creativecommons.org), which permits unrestricted use, distribution, and reproduction in any medium, provided the original author and source are credited.

For Full text $(2,178.7 \mathrm{kB})$ 